Boise State University

ScholarWorks

$10-2-2017$

\title{
2017 Boise State Research Data Environmental Scan Report
}

Michelle Armstrong

Boise State University

Heather Grevatt

Boise State University

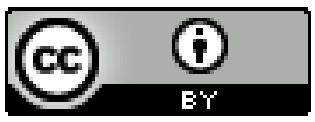

This work is licensed under a Creative Commons Attribution 4.0 License. 


\section{BOISE STATE RESEARCH DATA ENVIRONMENTAL SCAN REPORT}

\section{Purpose of the Environmental Scan}

In 2015, the Albertsons Library's Research Data Management Group established a 2-year strategic agenda which focused on increasing library service capacity, establishing partnerships with other campus stakeholders, and creating the technical infrastructure needed to ensure proper management of university research data assets. To inform this work during the next two year period, the group conducted an environmental scan of campus data management needs and activities. The survey was also designed to help other university administrators and campus partners understand the current state of research data, identify unmet needs, and highlight opportunities for increasing institutional capacity.

\section{Survey Process Utilized}

When planning for the assessment, the Research Data Management Group felt it was important to not only describe the present status of research data management but also provide broader context by comparing Boise State's efforts to other established models and best practices. The decision was made to utilize a research data maturity matrix known as CARDIO (Collaborative Assessment of Research Data Infrastructure and Objectives) $)^{1}$. With funding from JISC $^{2}$, the Digital Curation Centre ${ }^{3}$ created CARDIO to help organizations and groups to assess research data infrastructure and to visualize the future potential for their institution.

CARDIO is divided into three main sections: Organization, Technology, and Resources with a total of 30 questions. Within each section, participants are asked to rate their perception of the institution's maturity on a scale of $1-5$, with additional options for " $N / A$ : The statement is of no relevance to your situation." and "?: The statement is of relevance but you do not know enough about the situation to supply a rating." In addition to providing a ranked response, participants are encouraged to provide a rationale for their response through an open text box. A complete list of the questions and response options is provided in Appendix A.

During spring 2017, invitations were sent to 22 individuals who had some knowledge of or responsibility for research support. A total of 7 responses were received. While conducting the survey, it was determined that the original online instrument created by DCC was difficult for some participants and resulted in incomplete survey responses. As a result, an alternative, easier to use Google form version of the survey was created and offered to participants. As disseminating a finalized report via ScholarWorks would constitute human subjects research, the study received IRB approval before commencing.

\footnotetext{
${ }^{1}$ Digital Curation Centre. (n.d.). Collaborative assessment of research data infrastructure and objectives Retrieved from http://cardio.dcc.ac.uk/

2 Jisc. (n.d.). Retrieved from https://www.jisc.ac.uk/

${ }^{3}$ Digital Curation Centre. (n.d.). Collaborative assessment of research data infrastructure and objectives Retrieved from http://cardio.dcc.ac.uk/
} 
To supplement the small response rate, the library's Research Data Management Group contributed the results of their own examination of Boise State's policies and services which support how the university's research data is managed. Additionally, group members provided an overall analysis of each survey question and recommendations for improving Boise State's research infrastructure.

\section{Summary of Results}

In general, Boise State has made good progress in the area of developing the technological infrastructure needed to manage research data. The efforts of the Office of Information Technology (OIT) and elements of the Library's Research Data Management Group were seen as having made very positive contributions in this area. However, researcher knowledge and use of these services was perceived as very limited.

Throughout the survey responses and confirmed through the supplemental research by the library group, it was determined that individual researchers had primary responsibility for all research activities, grant management tasks, and oversight for any technological resources needed. Although some researchers work in groups or have access to high quality support staff, the workload burden many researchers face is significant and limits their ability to properly manage their research outputs. These stressors are heightened by a growing expectation from federal funders ${ }^{4}$ and journal publishers ${ }^{5}$ that research data be made publicly available, requiring significate curation and management work.

To continue to develop Boise State's research data infrastructure it is recommended that efforts are made to inform and help researchers take advantage of existing services, policies, and support staff when working with and managing research data. This includes increased interdepartmental awareness of and referral to appropriate units when researcher needs fall outside of an individual service provider's specific area.

Additionally, service providers should identify issues of scalability or potential service gaps and determine the resources needed for continued growth. The university can then build upon existing successes in the area of technological and data curation infrastructure by allocating needed funding and staff resources.

For additional information on this report, please contact:

${ }^{4}$ National Science Foundation. (2015). Today's data, tomorrow's discoveries: Increasing access to the results of research funded by the National Science Foundation. (NSF Publication No. NSF 15-52).

Retrieved from https://www.nsf.gov/pubs/2015/nsf15052/nsf15052.pdf and National Institutes of Health. (2015). National Institutes of Health plan for increasing access to scientific publications and digital scientific data from NIH funded scientific research. Retrieved from https://grants.nih.gov/grants/NIH-Public-Access-Plan.pdf

${ }^{5}$ Nature.com. (2017). Availability of data, material and methods. Retrieved from

http://www.nature.com/authors/policies/availability.html?foxtrotcallback=true 


\section{Authors}

Michelle Armstrong

Associate Professor/ Scholarly Communications and Data Management Librarian

michellearmstrong1@boisestate.edu

(208) 426-2580

\section{Key Personnel}

\section{Megan Davis}

Assistant Professor/ Research and Instruction Librarian

megandavis3@boisestate.edu

(208) 426-1621
Heather Grevatt

Assistant Professor/ Research and Instruction Librarian

heathergrevatt@boisestate.edu

(208) 426-3737

Amber Sherman

Assistant Professor/ Scholarly Communications and Data Management Librarian ambersherman704@boisestate.edu

(208) 426-4302 


\section{ORGANIZATION}

01: Data Ownership and Management / Who owns the data and associated documentation? Who has responsibility for data management? Are roles and responsibilities defined and accepted?

Respondents generally agreed about the maturity of this area. Indeed, this was the only question where all respondents who selected a numerical value, as opposed to the "?" or "N/A" options, chose the same value: 3 - A basic policy and guidance on data ownership is in place / Some individuals accept responsibility for data management but gaps exist - some data management activities lacking. Despite this agreement, the narrative responses showed a wide a range of understanding. Some answers indicated awareness of University Policy \#1090 “Intellectual Property," ${ }^{6}$ though it was not mentioned by name, while others indicated that they were not aware if there was a governing policy for data ownership. In addition, those who were aware of a governing policy described data ownership in such varying terms that a researcher consulting with multiple service providers could receive confusing or even contradictory statements. When responsibility for data management was specifically mentioned it was assigned to either the researcher or the Library Research Data Management Group. The need for better communication of existing policies to researchers was also mentioned, though there was no indication of where this communication should originate. The inconsistencies between responses suggest that better understanding and consistent communication of existing policies among service providers will be necessary before researchers can be expected to fully understand and implement those policies.

\section{O2: Data Policies and Procedures: Does the organization have written policies for data management and sharing? Are policies implemented?}

While there was confusion about the content or scope of data ownership policies, there was commonly awareness that such policies exist. In contrast, there was general awareness that current university policies either do not exist, or are not situationally relevant, to research data management. Responses indicated that some policy guides point to external sources and some policies are applied by the funder, which may or may not apply to all researchers. In addition, at least one respondent seemed to point to either University Policy \#1020 "University Records, Archives, and Publications"7 or Sections 10.7 "Retaining and Storing Signed Informed Consent Documents" and 11.6 "Retention of Records" of the Human Research Protection Program Guide ${ }^{8}$, however Policy \#1020 does not mention research records. The Human Research Protection Program Guide would only apply to researchers requiring Institutional Review Board approval. University Policy \#8060 “Information Privacy and Data Security" ${ }^{\prime 2}$ might also be considered relevant, however it more commonly applied to institutional data rather than research data. In order to elevate the maturity of this

\footnotetext{
${ }^{6}$ Boise State University. (2015). Policy title: Intellectual property. Retrieved from https://policy.boisestate.edu/governance-legal/intellectual-property/

${ }^{7}$ Boise State University. (2015). Policy title: University records, archives, and publications. Retrieved from https://policy.boisestate.edu/governance-legal/university-records-archives-publications/

${ }^{8}$ Institutional Review Board, Boise State University. (2015). Human research protection program guide. Retrieved from https://research.boisestate.edu/compliance/files/2015/07/IRB-Program-Guide July-2015.pdf

${ }^{9}$ Boise State University (2015). Policy title: Information privacy and data security. Retrieved from https://policy.boisestate.edu/information-technology/policy-title-information-privacy-and-data-security/
} 
area, it would be necessary to establish relevant, institutional policies before communicating those policies to researchers. As it exists now, researchers should be made aware that there may be relevant policies depending on their research circumstances.

03: Data Policy Review: Are policies reviewed and updated? Is the policy in line with wider context? Are updates reflected in new procedure?

There are a variety of policies, both local and national, that may impact the use, storage, and dissemination of university research data. In examining the university's practices, this question explores whether or not policies are being reviewed with the expectation that they serve as valuable tools for effectively managing data. Currently, perceptions are that policies related to research data are not systematically reviewed or are only reviewed on a limited basis. More advanced processes would involve reviewing current practices, updating policies accordingly, and communicating those changes to ensure good practice.

04: Sharing of Research Data / Access to Research Data: Are there systems in place to control access to data? Do you know of requirements to share data? Are there systems in place to share data? Are data accessed and shared in conformance with requirements?

Given that research data may contain valuable as well as potentially sensitive data, properly managing access to files can be critical to the research process. To examine the systems used to control this access, this question provided a range of possible responses from "Individuals store data and manage access requests" to "A mix of systems is in place to meet different access needs (e.g. shared storage, laptops, portable storage, commercial services). Security is often questionable due to the varied working practices." to "Access is systematically controlled in all cases through user rights and strong passwords". At Boise State there are well-managed systems which provide a variety of access options. However, individual use of the systems varies and little oversight exists to ensure adoption of these systems. For example, the recent availability of Globus services provides researchers with an efficient system for sharing data between institutions in other states or even other countries, but there is no enforcement within the system to prevent researchers from unknowingly violating Technology Transfer or Export Control policies. Greater systematic control is needed to improve the maturity of this area.

\section{5: Preservation and Continuity of Research / Does the institution understand and plan for preservation? Do you know of requirements to preserve data? Is there a process to select data for long-term preservation? Is there an infrastructure for long-term data management and preservation?}

Respondents indicated that this was a complicated area since 'long-term' can be defined differently by different service providers. While some service providers would consider long-term to mean 'in perpetuity' others would assume five to ten years. In addition, while service providers, such as Office of Information Technology or Albertsons Library, may be very aware of preservation and continuity of research issues, the researchers may not be as well versed. In terms of requirements, these may be put in place by funders, particularly in relation to federal grants. Per IRB Program Guide 11.6 Retention of Records, "Data will be stored for no less than three years after the completion of a project." Similarly, libraries maintain a culture of permanency and services such as ScholarWorks and DOI minting have expectations or even policy 
requirements for perpetual access. In the event that an item must be removed, citation access is still maintained. Albertsons Library has secured a memorandum of understanding with the Office of Information Technology for data sets issued DOIs and stored on OIT servers to ensure that the library remains in compliance with retention requirements. These varying preservation cultures and expectations may impact the nature of the information that researchers receive. Creating a more unified narrative may be necessary before researchers can be expected to successfully curate data for long-term preservation.

\section{6: Internal Audit of Research Activities: Are the research activities and resulting data well documented? Do you know what data you hold and where it is? Do you know how data are used?}

Participants consistently noted in both their narrative and ranked scores that individuals may have some knowledge about what data exists, but there is little effort to coordinate or organize this information. As with most data management responsibilities, information about data assets have either been left to the individual or not gathered at all. In a recent project conducted by library staff, a survey of almost 800 articles found that less than $1 \%$ of the data cited were publicly available ${ }^{10}$. In contrast to current practices, federal funders are now requiring principal investigators to treat data sets as reportable grant outcomes. Similarly, many journals are now requiring researchers to publish their data along with their article ${ }^{11}$. In response to these new requirements, Boise State researchers have begun to seek out ways that they can archive and publish data. These changes provide opportunities for the university to identify data assets, as well as how they are managed and publicly shared

\section{7: Monitoring and Feedback of Publication / Do you know how your data is used externally? Are there data publication policies and procedures? Are there data citation guidelines?}

Perhaps because it is a relatively new concept in research, respondent knowledge of data monitoring and citations was poor. This question was tied with T9: Metadata Tools for most respondents replying that they knew the topic was of relevance, but they did not have enough information to provide a numerical rating. Some considerations included assumptions of researcher responsibility and funder requirements. There was some thought that ScholarWorks might apply, but this would only be true for data sets published or shared via ScholarWorks. There is no entity on campus who monitors all data produced and tracks whether that data is published or openly disseminated. In other words, there is no University level data curator, though some activities of the Research Data Management Group, particularly a review of faculty publications to identify potentially shareable data, could be considered relevant. There are also no institutional policies that require open dissemination of data if possible. There are, however, signs that the university is moving in a more open direction, such as Albertsons Library adding the ability to issue DOIs for datasets. In addition, the current draft of the Office of Information Technology (OIT) Strategic Plan FY 2018-2022 includes a pillar of making data "available, accessible, and usable" to staff and clientele within the confines of applicable laws. ${ }^{12}$

\footnotetext{
${ }^{10}$ Armstrong, M., Davis, M., Grevatt, H., and Sherman, A. (2017). 2015-2016 “Data management strategic agenda - final report." Retrieved from http://dx.doi.org/10.18122/B2R59K

${ }^{11}$ Science. (2017). Data deposition. Science: editorial policies. Retrieved from http://www.sciencemag.org/authors/science-editorial-policies\#data-deposition

12 Office of Information Technology, Boise State University. (2017). OIT Strategic plan for fiscal years 2018-2022. Retrieved from https://oit.boisestate.edu/strategicplan/
} 
It could be argued that there is building university support for data publication, but limited infrastructure makes institutional oversight unrealistic.

08: Metadata Management: Do you understand the need to document data? Are research data labelled, annotated and organised? Are community norms and standards used where possible?

Responses in this area noted that data documentation was case dependent or not an appropriate responsibility for particular stakeholders. For example, OIT does not provide data description services and instead focuses on the technological infrastructure supporting the use of that data. Given the individual nature of each project, discipline-specific practices, and application of different metadata schema, this hands-off approach makes sense. An exception to this common practice was the data publishing services provided through ScholarWorks. For each data set made available through ScholarWorks, a descriptive metadata record is created which is DataCite compliant, allowing other indexing systems to easily harvest the content. This work also involves consultations with researchers, helping them appropriately document and organize their files. Researchers who take advantage of these services are hopefully better able to proactively manage their data, making it easier, in the long run, to publish and archive the files. Although it is reasonable to expect primary responsibility for data documentation to continued to be carried out by research staff, Boise State should utilize training materials to educate and increase understanding about this topic, encourage systematic organization and documentation of research data, and adopt community standards that advance these individual efforts.

\section{9: Legal Compliance / Is there an awareness of legislation that affects research data management e.g. DPA, Fol, EIR, IPR? Are data managed and shared in line with relevant legislation? Are there systems and policies to respond to relevant liabilities?}

Legal compliance regarding research data is a complex issue that includes the intersectional requirements of university, funder, publisher, state, and federal entities. Respondents generally agreed that while there are university systems or services with compliance expertise, it is incumbent upon the researcher to know what services or support they require and to request those services as needed. In turn, respondents indicated that they did not believe available services and support were well communicated to researchers. This is compounded by the complexity of compliance requirements at each level. As an anecdotal example, a researcher, though in full compliance with their federal funder requirements, did not realize that their data was possibly subject to restrictions from another federal entity. Had the researcher deposited their data in a third-party repository and not utilized University services, this oversight might have been missed and the researcher would be, unwittingly, out of legal compliance. These types of situations highlight the need for researchers to be well-educated about the potential implications of their research beyond the more commonly known laws such as HIPAA or FERPA. The standard of "freedom of dissemination" suggests that oversight on the part of the university (i.e. a mandatory review process before publication in order to assess legal compliance) would be inappropriate and potentially violate academic freedom. 
010: Intellectual Property Rights and Rights Management: Is it clear who owns data? Are data properly licensed for distribution and reuse? Are Intellectual Property Rights (IPR) managed appropriately so challenges can be addressed?

Interestingly, respondents provided mixed responses with equal numbers of individuals marking 1 (Data ownership is unclear) and 3 (Guidance and policies are in place for IPR / data ownership) to this question. Differences of opinions seemed to focus on the application of institutional policy and individual faculty capacity to effectively implement those policies. Currently, the university has in effect several policies which dictate ownership and distribution of research data ${ }^{13,14,15}$. However, implementation of those policies are usually left to the individual researcher and are dependent upon their understanding the policies and their compliance in notifying the appropriate departments. This management strategy is problematic as researchers are often unaware of or are confused about relevant policies. This complication is magnified with the involvement of student researchers who are dependent upon their faculty mentors to provide appropriate and legally correct advice. Consequently, issues involving ownership and dissemination of research data is handled on an ad hoc basis. Since issuing this survey, library staff have established standard licenses that faculty can select from when publishing their data through ScholarWorks. By doing this, the library and faculty engage in an assurance process regarding the intellectual property rights associated with the research data. In going forward the university may want to create more thorough self-service legal guidance for intellectual property that does not fall under the purview of Technology Transfer, similar to the direction provided to faculty regarding copyright compliance ${ }^{16}$.

\section{1: Disaster Planning and Continuity of Research / Are procedures in place to avoid data loss from technological failure? Have fallback options been considered for potential risks so research can continue? Are sustainability plans in place to safeguard data and ensure continued access?}

As with the issue of legal compliance, despite robust supports existing, it is incumbent on the researcher to utilize those services. Respondents indicated that OIT has disaster recovery policies and procedures in place. They also indicated that the use of centralized and well-managed data storage can protect researchers from risks, but that not many researchers are aware of or currently using those systems. Compounding the issue of communication was the belief that documentation for existing policies is not widespread or provided in accessible language. For example, an article by Research Computing from 2016 highlights the value of the OIT off-site disaster recovery data center, but it is difficult or impossible to locate on the regular website. ${ }^{17}$

\footnotetext{
${ }^{13}$ Office of Information Technology, Boise State University. (2016). Boise State University data use guidelines. Retrieved from https://oit.boisestate.edu/itgrc/boise-state-university-data-use-guidelines-1/

${ }_{14}$ Office of Information Technology, Boise State University. (2016). Boise State University data classification standard. Retrieved from https://oit.boisestate.edu/itgrc/boise-state-university-data-classification-standard/

${ }^{15}$ Boise State University. (2015) Policy title: Intellectual property. Retrieved from https://policy.boisestate.edu/governance-legal/intellectual-property/

${ }^{16}$ Office of General Counsel, Boise State University. (2017). Copyright. Retrieved from https://generalcounsel.boisestate.edu/copyright/

${ }_{17}$ Office of Information Technology, Boise State University. (2016). Google, Amazon and the Boise State public cloud. Retrieved from

https://oit.boisestate.edu/blog/2016/12/08/google-amazon-boise-state-public-cloud/
} 
This area appears to be one in which the issue is not necessarily that the systems are not in place, but that researchers are not aware of those systems or how to use them, despite a high-level of general knowledge among service providers. The Office of Emergency Management and Continuity Planning provides a number of resources, but it is unclear how widely used these resources are among institutes and labs. It is more likely that programs from Environmental Health, Safety, and Sustainability, such as their online training for biological safety, chemical safety, etc. are better utilized. A similar online training for researchers in data disaster planning might be a useful first step in improving communication and preparedness

\section{TECHNOLOGY}

T1: Technological Infrastructure: Does the technological infrastructure (e.g. network bandwidth, power, storage) meet research data management needs? Is there sufficient technological capacity to support the volume of research data?

Through their cyberinfrastructure development efforts, OIT has established a growing system to support researchers which includes storage for no or low costs, secure transfer options for large and sensitive data, and computational support for complex data sets. These efforts were favorably perceived by the respondents and one contributor specifically noted that the university is beginning to develop the needed technology infrastructure. However, they also felt that increased volume of research data may be needed to maximize the benefits the research data infrastructure could offer. Another respondent noted that user ability and awareness of what is available may be necessary before progress can be made in this area. Given the progress that has already been made in this area, researchers should be informed of the university's capabilities and encourages to utilizes these resources when appropriate.

T2: Appropriate Technologies / Is the necessary equipment available for research data management? Is the necessary software available for research data management? Are open standards understood and employed? Is data lifespan a consideration when choosing technology?

This area received mixed responses based on the perception that infrastructure and equipment are widely available, but software outside of standard institutional licenses must be provided by the researcher. This means the individual researcher must decide what standards they will use and how they will adhere to those standards. In addition, at least one College website encourages faculty to confer will the internal IT department, but does not require that they do so, only warning that certain purchases may be subject to General Counsel approval. ${ }^{18}$ It appears that individual laboratories are responsible for purchasing and maintaining any software necessary for their respective equipment, such as the mass spectrometer. Some departments and labs guide researchers toward freeware or open source products when available, but this varies. ${ }^{19}$ As researchers must provide their own software, this would in turn require sufficient funding, which may vary across grants and projects. The use of stable, non-proprietary software in order to facilitate data

${ }^{18}$ College of Engineering, Boise State University. (n.d.). Software at COEN. Retrieved from http://coen.boisestate.edu/its/software-at-coen/

${ }^{19}$ Northwest Tissue Mechanics Laborartory, Boise State University. (n.d.). Software. Retrieved from http://coen.boisestate.edu/ntm/software/ and College of Engineering, Boise State University. (n.d.).

Software at COEN. Retrieved from http://coen.boisestate.edu/its/software-at-coen/ 
sharing is also a potential consideration for this area, however the financial restraints likely take precedence. In was interesting to note that no respondents mentioned the Systems Architecture Review Board (SARB) as they provide software support services and all software purchases over $\$ 25,000$ are subject to SARB review. ${ }^{20}$ It is likely that college or department IT professionals are more familiar with this resource and in turn can direct researchers to the services, but the scan did not receive any responses from service providers in these positions. Making researchers, particularly those with limited departmental support, better aware of SARB services may help improve perceptions of the available infrastructure.

\section{T3: Ensuring Availability: Are there policies and procedures in place for robust data backup and redundancy? Are there policies and procedures in place to synchronise multiple copies of data? How is the use of removable or local storage regulated?}

Respondents of this question valued the managed computing resources available through OIT as a strategy for mitigating access problems. Utilizing an established data retention period, backups on these systems can be used to recover data for a limited period. Additionally, OIT provides off site backups and can handle most disasters. Similarly, ScholarWorks has both vendor provided backups and the library retains local archival copies. However, as valuable as these procedures are, researchers who do not take advantage of these services or lack the technological skills or resources to ensure availability are at risk for data loss. Addressing these deficits should involve increasing the understanding of the risks for technology obsolescence, adoption of open standards when possible, and implementation of institutional strategies to prevent research data loss.

\section{T4: Managing data integrity / Is data integrity monitored and managed? How is data integrity validated and restored? How is storage media integrity validated?}

As with some other topics, respondents were confident in the Office of Information Technology's ability to manage the integrity of the storage media, but were not confident in researchers' knowledge of data integrity practices or willingness to employ those practices. The human element in managing data integrity was mentioned with the concern that the best monitored data service will not work unless researchers use it. There was also the concern that if the data is made inaccurate through direct human intervention, the system may not find or recognize the error. In relation to storage media integrity University Policy \#8020 Section I.1.e. Backups, states, "Appropriate backups of the server's OS, applications, data, and configuration documentation must be maintained, with type and frequency of the backups dependent upon the criticality of service(s) hosted." It may be unrealistic to propose a university policy requiring the use of approved storage media for all data as opposed to current policies that only address sensitive data, however at a minimum better communication is needed. Researchers should be made better aware of available resources and the reasons to use these resources. In addition, better oversight or education regarding research protocol and best practices, may help prevent the human error element of data integrity. Regular adoption of lab manuals, lab notebook standards, and limited access to raw data sets, as opposed to files specifically created for manipulation may help in this area.

${ }^{20}$ Project Management Office, Boise State University. (n.d.). System Architecture Review Board (SARB). Retrieved from https://oit.boisestate.edu/pmo/sarb/ 
T5: Obsolescence: Is potential obsolescence a consideration when selecting technologies for data and data management (e.g., formats, systems, hardware and storage media)? Are open formats and standards prioritised where applicable? How are risks of technological obsolescence identified and resolved?

As with all technology, software and hardware will eventually wear out or need to be replaced. When this happens, data stored on older or outdated technology may be at risk for loss. Because of the difference in skills and resources available to the individual researcher versus centrally managed technology, concerns about obsolescence differ. Both Albertsons Library and OIT have actively considered how to provide long-term access or support. However, individual researchers most likely do not have these resources and are a great risk for losing their data. There is no clear understanding how or even if they are attempting to do this. As with T2: Appropriate Technologies and T3: Ensuring Availability, more universal guidance on obsolescence and data loss issues may help support researchers who choose not to use OIT provided resources.

\section{T6: Managing technological change / How are technology changes planned and implemented? How are processes and changes to those processes documented?}

Technological change was generally regarded as a more mature area of research data management. Specific considerations mentioned were a focus on non-disruptive change, including the ability to move data without impacting researchers, and an extremely low rate of unavailability due to hardware updates. It appears that technology changes are primarily governed by two organizations on campus. The IT Governance Council "provides visionary leadership for the adoption and application of university-wide IT resources..." ${ }^{21}$ The IT Priority Committee "functions as the steering committee for the Office of Information Technology." 22 Since this area is generally considered more mature, one potential area for improvement may simply be communication and transparency. Except for the current draft of the OIT Strategic Plan, there is little mention of the committees or their activities which could give a perception that technological change is not managed or applied equitably across campus, even though this may not be true. Similarly, better awareness of departmental IT services and activities could help cross-disciplinary researchers better understand how IT services are administered across campus.

\section{T7: Security Provisions: Are there adequate information security policies and procedures in place? Are technological risks managed? Is access controlled? Are security provisions tested?}

Boise State has established several technology security policies. Boise State University Policy - 8060: Information $^{23}$, Privacy and Data Security, Boise State University Data Use Guidelines ${ }^{24}$, and Boise State Data

\footnotetext{
${ }^{21}$ Office of Information Technology, Boise State University. (n.d.). IT Governance Council. Retrieved from https://oit.boisestate.edu/aboutoit/governance/itgc/

22 Office of Information Technology, Boise State University. (n.d.). IT Priority Committee. Retrieved from https://oit.boisestate.edu/aboutoit/governance/it-priority-committee/

${ }^{23}$ Boise State University. (2016). Policy title: Information privacy and data security. Retrieved from https://policy.boisestate.edu/information-technology/policy-title-information-privacy-and-data-security/

${ }^{24}$ Office of Information Technology, Boise State University. (2016). Boise State University data use guidelines. Retrieved from https://oit.boisestate.edu/itgrc/boise-state-university-data-use-guidelines-1/
} 
Classification Standard ${ }^{25}$ provides guidelines for how research data should be managed. For researchers utilizing OIT storage, they are able to depend upon a well-managed system where risks have been minimized and access to research files is limited to authorized staff. However, for many individual projects, implementation of these policies is left to the researcher with no central oversight. This gap between the perception of OIT services and efforts by individual researchers is reflected in the varied ranked scores provided. Given the importance of securing research data, advancements in this area could include increasing awareness of security issues and related policies, as well as broader use of OIT services when appropriate for research projects.

\section{T8: Security Processes / Are security threats monitored and resolved? Is security infrastructure operated and maintained appropriately?}

Despite funding anecdotally being a consistent concern across research data management services, Security Processes was one of the few questions where respondents specifically mentioned that services could be expanded if additional funding was available. It is a major consideration for relevant parties, but in the interest of cybersecurity cannot always be discussed openly. In addition, several respondents felt that security processes are in place, but rely on consistent use by researchers, which cannot be guaranteed. There is likely an expectation that security is handled by OIT and is not an immediate researcher concern. Some faculty may also be unfamiliar with data classification or appropriate security measures for different classifications. Security is one of the few research data management topics with an associated university level policy. University Policy \#8060 Information Privacy and Data Security, among other subjects, defines data sensitivity levels and outlines responsibilities by group status (e.g. custodians, users, managers, or information service providers. $)^{26}$ Continued efforts on the part of OIT to build a culture of security awareness and compliance may help develop the maturity of this area.

\section{T9: Metadata tools: Are appropriate technologies available to create metadata in line with standards? Is the process of metadata creation automated where possible? Are tools to make use of metadata available?}

As a specialized topic, metadata tools and supports are often misunderstood which is reflected in the numerical scores received. Of the respondents who contributed, one individual ranked the university as a (1: No tools are available to aid metadata creation and use), while another person gave the university the highest rank on the maturity matrix (5: A strategy is implemented to maintain good practice and ensure appropriate metadata tools continue to be in place). The other three respondents indicated that they did not know what the status of this university's capacity was in this area. Essential to discovery and use, descriptive metadata should be created utilizing best practices and, whenever possible, in compliance with appropriate schema. Albertsons Library has made good progress in helping researchers create appropriate metadata for data sets ingested into ScholarWorks. However, data publishing occurs at the end of the

${ }^{25}$ Office of Information Technology, Boise State Universtiy. (2016). Boise State University data classification standard. Retrieved from https://oit.boisestate.edu/itgrc/boise-state-university-data-classification-standard/

${ }^{26}$ Boise State University. (2016). Policy title: Information privacy and data security. Retrieved from https://policy.boisestate.edu/information-technology/policy-title-information-privacy-and-data-security/ 
research project and opportunities can be missed to gather key pieces of metadata. Although the library can consult with researchers on appropriate metadata schema and help set up metadata gathering tools, these services have not been advertised due to limited staff time. Additionally, researchers who are aware of these supports do not always ask for help. To build upon this work, greater emphasis can be placed upon early consultation and planning for data documentation and metadata gathering.

\section{T10: Institutional Repository / Do you have an Institutional Repository that accepts data, not just publications? To what extent is the repository embedded in research culture/process?}

Despite a comparatively low average score, respondents indicated that ScholarWorks is well-integrated into the University research process and culture. The idea that an institutional repository for research data is only "in development" may reflect the new addition of data services to other, already established publication activities. Indeed, data as a research output formatted for and worthy of dissemination through a repository is a newer concept among the research community as a whole and Boise State is likely comparable to other institutions in the United States. Perceptions of this area could likely be improved through continued marketing and communication of available services. As with other research data management issues, improved awareness among service providers is a critical step in ensuring that researchers receive accurate and timely information about available services on campus. This was perhaps best reflected by the respondent who expressed that they did not have enough information to speak to many of the technology related questions, but felt that they should have a better knowledge of those issues.

\section{RESOURCES}

\section{R1: Data Management Costs and Sustainability: Are the costs associated with data management understood and accounted for? Are plans in place to ensure resourcing for data management is sustained? Is research data management embedded as a core function and financed appropriately?}

Traditionally research data management has not been prioritized for universities, let alone individual researchers. As a consequence, Boise State has only started to organize its data management efforts at an institutional level. Departments such as OIT were willing to allocate existing funds and seek additional grant funds to provide cyberinfrastructure services which contribute to research data management. As one respondent noted, they had not run out of funding yet and assumed that since research is a core function of the university, financial resources would continue to be available. However, other campus groups, such as Albertsons Library have been unsuccessful in obtaining permanent funds for the services they provide, leaving them vulnerable to changes in vendor prices and limiting their ability to expand their support to the entire campus. To address this problem, the library has established a strategic agenda activity to create a cost estimate process as a method for identifying expenses associated with managing, preserving, and publishing research data ${ }^{27}$. The expectation is that costs will be incorporated into grant budgets and allocated appropriately to help support groups who have assumed additional responsibilities for data management.

${ }^{27}$ Sherman, A., Grevatt, H., Davis, M., Armstrong, M. (2017). Albertsons Library data management strategic agenda summer 2017 - summer 2019. Retrieved from http://dx.doi.org/10.18122/B2K709 


\section{R2: Business Planning / Is data management a consideration when developing business plans? Is research data management embedded as a core function of the organisation?}

This questions received limited responses, but those responses were generally favorable. Respondents believed that data management is embedded as a core function of business planning, but is not well-publicized. As with R8: Number of Staff for Data Management, it was unclear whether respondents were considering their localized business planning groups or institution level behaviors. Increased transparency or reporting on the part of groups related to research data management may help create better awareness of business planning activities and identify planning gaps. Service providers looking to support research data management as an element of business planning may refer to Goal 3 of the Boise State University Strategic Agenda, "Build infrastructure to keep pace with growing research and creative activity. ${ }^{28}$ As data management requirements from funders become increasingly complex this is an area that may see significant expansion.

\section{R3: Technological Resources Allocation: Are resources sufficient to ensure sustainability and scalability of technology provision? Is technology investment appropriate to data management demands? Are staff equipped to fully exploit technological resources?}

Over the past several years, the Office of Information Technology has provided leadership in the development of a university cyberinfrastructure, providing increased storage, server support, and High Performance Computing resources. OIT has also established the Research Computing Support services, offered computation and visualization support, data and source control management, and grant development services for proposals involving computing resources. To a lesser degree, the library has also implemented several services to support the publishing of research data including the creation of digital research data collections ${ }^{29}$ in ScholarWorks and minting of $\mathrm{DOIs}^{30}$ to assist in data citation and discovery. Only the DOI services have been financially supported through a 3 year agreement with the MILES grant project for the EZID license. All other work has been the result of staff reallocation and the adoption of additional responsibilities. Overall, these advances are perceived favorably and are recognized as established services available to researchers. However, variations in numerical responses seemed to be based upon perceived limitations in long-term coordination of and support for these services. No written responses were provided.

R4: Risk Management / Does the organisation understand and proactively manage risks associated with data management? Is there capacity to mitigate risks when identified?

Risk management was perceived as an issue that is well understood by the Office of Information Technology, particularly Research Computing, and Albertsons Library. At least one respondent expressed that they were

${ }^{28}$ Office of the Provost, Boise State University. (n.d.). Goals and strategies for focus on effectiveness. Retrieved from https://academics.boisestate.edu/provost/goals-and-strategies/

${ }^{29}$ Boise State Data Sets. (2017). Retrieved from http://scholarworks.boisestate.edu/data sets/

${ }^{30}$ Can ScholarWorks help me get a DOI? (n.d.) In Frequently asked questions. Retrieved from http://scholarworks.boisestate.edu/faq.html\#faq-42 
not sure whether a University level risk register exists. Generally, a risk register is an analysis tool that can be used to identify and organize information related to potential IT risks. Common fields include a unique identifier (such as a numerical designation), the risk name, risk type, potential impact, priority, date or other triggers that could initiate the risk, a mitigation strategy, mitigation actions to be taken, and columns to record instances of occurrence. A cursory search of the Boise State web presence did not locate any university maintained or locally maintained risk register style documents. It is important to note that risks are not always strictly technological. Loss of key personnel, vendor mergers or acquisitions, and theft of equipment are all components of risk as well. Balancing the need for restricted access to internal security documents, an area of growth might be to create greater transparency of risk issues and best practices in order to ensure researchers are well aware of potential concerns.

\section{R5: Transparency of Resource Allocation: Is it clear how resources are allocated to support research data management? Is the income associated with research data management clearly identified and traceable for audit purposes?}

Very little information was offered in response to this question. Only one individual provided a ranked response ("Some data management costs may be identifiable in budgets but practice is ad hoc"), while the other four individuals indicated that the question was not applicable to their situation or they were unsure. No narrative responses were received. As indicated in questions R1 Data Management Costs and Sustainability and R3 Technological Resources Allocation, the university has allocated funds to develop the university's cyberinfrastructure. However, no additional funds have been allocated at a university-level specifically for data management activities. Consequently, there have been no opportunity to clearly identify how resources are used in this area.

\section{R6: Sustainability of Funding for Data Management and Preservation / Are there sustainable financial resources for research data management? Are efforts made to seek additional funding sources? Are central resources allocated appropriately to support research data management activity?}

Unsurprisingly, the issue of funding received the lowest average score among respondents. As described within the survey instrument language associated with the average score, "Resources to support data management are often from short-term competitive funding and as such cannot be reliably sustained." One respondent specifically mentioned that their services are rarely incorporated into grant submissions as a potential cost. Even when they are included the scope is generally short-term, perhaps the life of the grant, without consideration for long-term data storage. Indeed, costing for elements of research data management is a relatively new field and though literature exists, it is lacking. As many data management services are performed by departments typically associated with indirect costs, creating a culture of direct cost services can be confusing and complex. Without clear delineations between standard services and exceptional services, those that the department cannot offer without additional funding support, researchers cannot be expected to account for the additional costs. Some major funders, such as National Institutes of Health (NIH) and Research Councils UK allow researchers to include data sharing, storage, or archiving costs as a part of their grant, but NIH admits that newer researchers may have trouble effectively 
estimating associated costs. ${ }^{31}$ In addition to advocating for more allocation of central resources for research data management support, it is incumbent upon university service providers who would like compensation for specific levels of service to create documentation or training that assists researchers with cost estimation..

R7: Data Management Skills: Do research staff have the skills they need to undertake research data management? Is there a sufficient support provision and appropriate alignment of skills with roles? Are skills shared within the institution (e.g., to mitigate loss of knowledge due to staff turnover)?

Of the ranked responses received, most participants indicated that "A small number of individuals have data management skills, but their departure would leave a skills gap that would be difficult to fill." Because no narrative information was provided it is difficult to fully identify what human resources are available on campus. A group of individuals from various campus units has been meeting to identify points of intersections in their work and how each member contributes to the research data lifecycle. However, there has been no effort yet to identify available skills or where there may be overlap or deficits. To increase Boise State's capacity in this area, data management skills can be added to official job descriptions, sufficient support provided to maintain those skills, and systematic cross-training across campus units when appropriate to ensure adequate staff resources and competencies.

R8: Number of Staff for Data Management / Are there enough members of staff to undertake and/or support research data management? Are adequate funds available to maintain necessary staff levels? Do you understand the staffing requirements to ensure data management success?

It is difficult to assess how respondents felt about staffing levels because no narrative responses were recorded. This means that is impossible to know whether respondents were considering their own localized staffing levels or staffing across university departments when they assigned a relatively low average score. Without a thorough review of existing workloads, and perhaps strategic agendas in order to determine where gaps have already been identified and formally acknowledge, it is challenging to speak to this area. Identifying staffing gaps may be a necessary step in supporting R6: Sustainability of Funding for Data Management and Preservation. Administrators would rightly expect justification of the need for additional staff from a funding perspective.

R9: Staff Development Opportunities: Do researchers have access to data management training and other development opportunities? Is training appropriate for researchers' needs and up to date? Are staff development needs identified, monitored and responded to?

Having a workforce capable of effectively managing university research assets is essential for a mature data management infrastructure. Training and other staff development opportunities are common practice to ensure this appropriate workforce development and Boise State has engaged in some of these activities. Although no narrative responses were received to this question and only three individuals provided ranked

\footnotetext{
${ }^{31}$ National Institutes of Health. (2003). Budget Justification. NIH data sharing policy and implementation guidance. Retrieved from https://grants.nih.gov/grants/policy/data_sharing/data_sharing_guidance.htm
} 
responses, the perception is that training provided in some cases or by request. For example, campus groups have offered some basic research data management trainings, but most opportunities have focused on providing general overviews (Office of Sponsored Projects 2014 presentations on data management plans) or have been one part of a larger outreach activity (Research Computing's Coffee \& Donuts: The Research Data Management Lifecycle event). Although useful for awareness raising, these types of activities are insufficient to help researchers develop needed skills. To help address this gap, Albertsons Library developed training modules for graduate students which can be incorporated as part of a course. Although a good start, the curriculum still needs to be implemented and assessed. Research Computing and the Department of Computer Science have also been working to increase workforce capacity for Boise State and beyond. In addition to regular networking events, Research Computing has begun sponsoring user groups for different software packages such as MATLAB, Python, and R. Additionally the computer sciences department is offering an introductory data sciences class to increase awareness and participation in this area. Going forward, a mature infrastructure in this area could include a budget for staff development, specific research data training that is widely promoted, evaluation of and response to staff development needs, and adoption of university-wide reviews to identify and ensure adequate staff capabilities. 
"CARDIO (Collaborative Assessment of Research Data Infrastructure and Objectives) Questions" by Digital Curation Centre is licensed under a Creative Commons Attribution 4.0 International License.

\section{ORGANIZATION}

Organisational infrastructure covers the policies, procedures, systems, and skills needed for research data management. The key underlying questions is: Are the policies and systems in place sufficiently well known, understood and implemented to ensure research data are effectively managed and shared?

01: Data Ownership and Management: Who owns data and associated documentation? Who has responsibility for data management? Are roles and responsibilities defined and accepted?

\begin{tabular}{|c|c|c|c|c|c|c|}
\hline $\begin{array}{l}N / A \text { : The statement } \\
\text { is of no relevance to } \\
\text { your situation. }\end{array}$ & $\begin{array}{l}\text { ?: The statement is } \\
\text { of relevance but you } \\
\text { do not know enough } \\
\text { about the situation } \\
\text { to supply a rating. }\end{array}$ & $\begin{array}{l}\text { 1: Data ownership is } \\
\text { unclear / Nobody } \\
\text { accepts } \\
\text { responsibility for } \\
\text { data management }\end{array}$ & $\begin{array}{l}\text { 2: Ownership of } \\
\text { data is assigned ad } \\
\text { hoc / Responsibility } \\
\text { for data } \\
\text { management is } \\
\text { implied but not } \\
\text { explicit }\end{array}$ & $\begin{array}{l}\text { 3: A basic policy } \\
\text { and guidance on } \\
\text { data ownership is in } \\
\text { place / Some } \\
\text { individuals accept } \\
\text { responsibility for } \\
\text { data management } \\
\text { but gaps exist - } \\
\text { some data } \\
\text { management } \\
\text { activities lacking }\end{array}$ & $\begin{array}{l}\text { 4: Data ownership is } \\
\text { routinely } \\
\text { documented / Roles } \\
\text { and responsibilities } \\
\text { for data } \\
\text { management are } \\
\text { well defined. } \\
\text { Individuals accept } \\
\text { their responsibilities } \\
\text { and take them } \\
\text { seriously. }\end{array}$ & $\begin{array}{l}\text { 5: Systems to define } \\
\text { ownership and } \\
\text { license data function } \\
\text { well / There is a } \\
\text { co-ordinated } \\
\text { approach to data } \\
\text { management across } \\
\text { roles }\end{array}$ \\
\hline
\end{tabular}

02: Data Policies and Procedures: Does the organisation have written policies for data management and sharing? Are policies implemented?

\begin{tabular}{l|l|l|l|l|l|l}
$\begin{array}{l}\text { N/A: The statement } \\
\text { is of no relevance to } \\
\text { your situation. }\end{array}$ & $\begin{array}{l}\text { ?: The statement is } \\
\text { of relevance but you } \\
\text { do not know enough } \\
\text { about the situation } \\
\text { to supply a rating. }\end{array}$ & $\begin{array}{l}\text { 1: Data } \\
\text { management and } \\
\text { sharing are not } \\
\text { considered }\end{array}$ & $\begin{array}{l}\text { 2: Local guidelines } \\
\text { or unwritten rules for } \\
\text { data management } \\
\text { may be in place }\end{array}$ & $\begin{array}{l}\text { 3: Data policies are } \\
\text { formalised }\end{array}$ & $\begin{array}{l}\text { 4: Policies are } \\
\text { supported by tools, } \\
\text { guidance and } \\
\text { infrastructure }\end{array}$ & $\begin{array}{l}\text { 5: Data policies are } \\
\text { ratified, well } \\
\text { communicated and } \\
\text { adopted. Data } \\
\text { management and } \\
\text { sharing is effective. }\end{array}$ \\
\hline
\end{tabular}

03: Data Policy Review: Are policies reviewed and updated? Is the policy in line with wider context? Are updates reflected in new procedure?

\begin{tabular}{|c|c|c|c|c|c|c|}
\hline $\begin{array}{l}\text { N/A: The statement } \\
\text { is of no relevance to } \\
\text { your situation. }\end{array}$ & $\begin{array}{l}\text { ?: The statement is } \\
\text { of relevance but you } \\
\text { do not know enough }\end{array}$ & $\begin{array}{l}\text { 1: Data policies } \\
\text { aren't revisited (if } \\
\text { they exist at all) }\end{array}$ & $\begin{array}{l}\text { 2: Data policies are } \\
\text { periodically } \\
\text { reviewed }\end{array}$ & $\begin{array}{l}\text { 3: The data } \\
\text { management } \\
\text { landscape is }\end{array}$ & $\begin{array}{l}\text { 4: Updates to data } \\
\text { policy are well } \\
\text { communicated and }\end{array}$ & $\begin{array}{l}\text { 5: Amendments to } \\
\text { the data policy are } \\
\text { reflected in new }\end{array}$ \\
\hline
\end{tabular}




\begin{tabular}{|l|l|l|l|l|l|}
\hline & $\begin{array}{l}\text { about the situation } \\
\text { to supply a rating. }\end{array}$ & & & $\begin{array}{l}\text { monitored to inform } \\
\text { policy changes }\end{array}$ & $\begin{array}{l}\text { support is given for } \\
\text { implementation }\end{array}$ \\
$\begin{array}{l}\text { procedures. The } \\
\text { data policy } \\
\text { continues to be } \\
\text { referenced as a } \\
\text { model of good } \\
\text { practice. }\end{array}$ \\
\hline
\end{tabular}

06: Internal Audit of Research Activities: Are the research activities and resulting data well documented? Do you know what data you hold and where it is? Do you know how data are used?

\begin{tabular}{|c|c|c|c|c|c|c|}
\hline $\begin{array}{l}N / A \text { : The statement } \\
\text { is of no relevance to } \\
\text { your situation. }\end{array}$ & $\begin{array}{l}\text { ?: The statement is } \\
\text { of relevance but you } \\
\text { do not know enough } \\
\text { about the situation } \\
\text { to supply a rating. }\end{array}$ & $\begin{array}{l}\text { 1: Poor awareness } \\
\text { of research activities } \\
\text { and data outputs }\end{array}$ & $\begin{array}{l}\text { 2: Individuals have } \\
\text { pockets of } \\
\text { knowledge about } \\
\text { certain research } \\
\text { projects and } \\
\text { datasets but little/no } \\
\text { overview }\end{array}$ & $\begin{array}{l}\text { 3: A central record } \\
\text { is kept / good } \\
\text { documentation is } \\
\text { provided on } \\
\text { research activities } \\
\text { and data }\end{array}$ & $\begin{array}{l}\text { 4: You know (or can } \\
\text { easily find out): } \\
\text { What research has } \\
\text { been undertaken; } \\
\text { What data are held; } \\
\text { Where data are } \\
\text { held; How data are } \\
\text { used. }\end{array}$ & $\begin{array}{l}\text { 5: High levels of } \\
\text { knowledge exist } \\
\text { about research } \\
\text { activities and data, } \\
\text { and this is routinely } \\
\text { put to good use. } \\
\text { Exemplary systems } \\
\text { for research } \\
\text { information } \\
\text { management. }\end{array}$ \\
\hline
\end{tabular}

07: Monitoring and Feedback of Publication: Do you know how your data is used externally? Are there data publication policies and procedures? Are there data citation guidelines?

\begin{tabular}{|l|l|l|l|l|l|l|}
$\begin{array}{l}\text { N/A: The statement } \\
\text { is of no relevance to } \\
\text { your situation. }\end{array}$ & $\begin{array}{l}\text { ?: The statement is } \\
\text { of relevance but you } \\
\text { do not know enough } \\
\text { about the situation } \\
\text { to supply a rating. }\end{array}$ & $\begin{array}{l}\text { 1: Data are not } \\
\text { typically published } \\
\text { or made available }\end{array}$ & $\begin{array}{l}\text { 2: Each researcher } \\
\text { defines their own } \\
\text { publication } \\
\text { workflow. Little } \\
\text { co-ordination or } \\
\text { guidelines }\end{array}$ & $\begin{array}{l}\text { 3: Guidelines for } \\
\text { publishing and citing } \\
\text { data are provided. } \\
\text { Some support is } \\
\text { available }\end{array}$ & $\begin{array}{l}\text { 4: Agreed } \\
\text { procedures and } \\
\text { mechanisms are in } \\
\text { place to publish, link } \\
\text { to and cite data }\end{array}$ & $\begin{array}{l}\text { 5: Systems function } \\
\text { well to ensure data } \\
\text { are published and } \\
\text { can be cited. } \\
\text { Published data are } \\
\text { monitored and } \\
\text { statistics are logged } \\
\text { (e.g. views, } \\
\text { citations, feedback). }\end{array}$ \\
\hline
\end{tabular}

08: Metadata Management: Do you understand the need to document data? Are research data labelled, annotated and organised? Are community norms and standards used where possible?

\begin{tabular}{|l|l|l|l|l|l|l|}
$\begin{array}{l}\text { N/A: The statement } \\
\text { is of no relevance to } \\
\text { your situation. }\end{array}$ & $\begin{array}{l}\text { ?: The statement is } \\
\text { of relevance but you } \\
\text { do not know enough }\end{array}$ & $\begin{array}{l}\text { 1: Metadata is an } \\
\text { unfamiliar concept. } \\
\text { Low engagement }\end{array}$ & $\begin{array}{l}\text { 2: Practice varies by } \\
\text { individual - some } \\
\text { label, organise and }\end{array}$ & $\begin{array}{l}\text { 3: Metadata is well } \\
\text { understood and } \\
\text { support/guidance is }\end{array}$ & $\begin{array}{l}\text { 4: Data are well } \\
\text { labelled, annotated } \\
\text { and systematically }\end{array}$ & $\begin{array}{l}\text { 5: Metadata are } \\
\text { routinely created } \\
\text { and well managed. }\end{array}$ \\
\hline
\end{tabular}




\begin{tabular}{|l|l|l|l|l|l|}
\hline & $\begin{array}{l}\text { about the situation } \\
\text { to supply a rating. }\end{array}$ & $\begin{array}{l}\text { with the need to } \\
\text { document data. }\end{array}$ & $\begin{array}{l}\text { document data well, } \\
\text { whereas others } \\
\text { don't consider this at } \\
\text { all }\end{array}$ & $\begin{array}{l}\text { provided to make } \\
\text { sure data are } \\
\text { documented. } \\
\text { Metadata standards } \\
\text { are typically used. }\end{array}$ & $\begin{array}{l}\text { organised. The } \\
\text { metadata ensures it } \\
\text { is easy for } \\
\text { researchers to } \\
\text { understand each } \\
\text { other's data. }\end{array}$ \\
\hline
\end{tabular}

09: Legal Compliance: Is there an awareness of legislation that affects research data management e.g. DPA, Fol, EIR, IPR? Are data managed and shared in line with relevant legislation? Are there systems and policies to respond to relevant liabilities?

\begin{tabular}{|l|l|l|l|l|l|l|}
$\begin{array}{l}\text { N/A: The statement } \\
\text { is of no relevance to } \\
\text { your situation. }\end{array}$ & $\begin{array}{l}\text { ?: The statement is } \\
\text { of relevance but you } \\
\text { do not know enough } \\
\text { about the situation } \\
\text { to supply a rating. }\end{array}$ & $\begin{array}{l}\text { 1: Low awareness } \\
\text { of relevant } \\
\text { legislation }\end{array}$ & $\begin{array}{l}\text { 2: Data may be } \\
\text { managed according } \\
\text { to legislation at } \\
\text { times, but } \\
\text { compliance is } \\
\text { uncertain and risks } \\
\text { high }\end{array}$ & $\begin{array}{l}\text { 3: Guidance and } \\
\text { support is available } \\
\text { to adhere to } \\
\text { relevant legislation. } \\
\text { Researchers } \\
\text { understand how } \\
\text { legislation affects } \\
\text { data management } \\
\text { practice. }\end{array}$ & $\begin{array}{l}\begin{array}{l}\text { 4: Policies and } \\
\text { associated systems } \\
\text { are in place to } \\
\text { manage data in line } \\
\text { with legislation }\end{array} \\
\text { shown to work } \\
\text { effectively. Staff are } \\
\text { aware of legislation } \\
\text { and accept various } \\
\text { tasks / } \\
\text { responsibilities to } \\
\text { conform. }\end{array}$ \\
\hline
\end{tabular}

010: Intellectual Property Rights and Rights Management: Is it clear who owns data? Are data properly licensed for distribution and reuse? Are Intellectual Property Rights (IPR) managed appropriately so challenges can be addressed?

\begin{tabular}{l|l|l|l|l|l|l|}
$\begin{array}{l}\text { N/A: The statement } \\
\text { is of no relevance to } \\
\text { your situation. }\end{array}$ & $\begin{array}{l}\text { ?: The statement is } \\
\text { of relevance but you } \\
\text { do not know enough } \\
\text { about the situation } \\
\text { to supply a rating. }\end{array}$ & $\begin{array}{l}\text { 1: Data ownership is } \\
\text { unclear }\end{array}$ & $\begin{array}{l}\text { 2: Intellectual } \\
\text { Property Rights are } \\
\text { assigned ad hoc }\end{array}$ & $\begin{array}{l}\text { 3: Guidance and } \\
\text { policies are in place } \\
\text { for IPR / data } \\
\text { ownership }\end{array}$ & $\begin{array}{l}\text { 4: Data ownership is } \\
\text { routinely } \\
\text { documented. Data } \\
\text { are properly } \\
\text { licensed for } \\
\text { distribution and } \\
\text { reuse. }\end{array}$ & $\begin{array}{l}\text { 5: Functioning } \\
\text { systems are in place } \\
\text { so: ownership is } \\
\text { clear; IPR is } \\
\text { managed; disputes } \\
\text { can be resolved. }\end{array}$ \\
\hline
\end{tabular}

011: Disaster Planning and Continuity of Research: Are procedures in place to avoid data loss from technological failure? Have fallback options been considered for potential risks so research can continue? Are sustainability plans in place to safeguard data and ensure continued access?

\begin{tabular}{|c|c|c|c|c|c|c|}
\hline $\begin{array}{l}\text { N/A: The statement } \\
\text { is of no relevance to } \\
\text { your situation. }\end{array}$ & $\begin{array}{l}\text { ?: The statement is } \\
\text { of relevance but you } \\
\text { do not know enough } \\
\text { about the situation } \\
\text { to supply a rating. }\end{array}$ & $\begin{array}{l}\text { 1: Data } \\
\text { management } \\
\text { activities focus on } \\
\text { the day-to-day. No } \\
\text { thought for }\end{array}$ & $\begin{array}{l}\text { 2: Some awareness } \\
\text { of potential data } \\
\text { management risks } \\
\text { but few take } \\
\text { preventative action }\end{array}$ & $\begin{array}{l}\text { 3: Policies and } \\
\text { plans are in place } \\
\text { for disaster recovery } \\
\text { and long-term } \\
\text { sustainability }\end{array}$ & $\begin{array}{l}\text { 4: Disaster recovery } \\
\text { plans are } \\
\text { accompanied by } \\
\text { procedures for } \\
\text { implementation. } \\
\text { Data loss, a break in }\end{array}$ & $\begin{array}{l}\text { 5: Disaster recovery } \\
\text { plans are routinely } \\
\text { tested and shown to } \\
\text { be effective. } \\
\text { Succession plans } \\
\text { (e.g. an alternative }\end{array}$ \\
\hline
\end{tabular}




\begin{tabular}{|l|l|l|l|l|l|}
\hline & & $\begin{array}{l}\text { long-term or } \\
\text { disaster planning. }\end{array}$ & $\begin{array}{l}\text { or have alternatives } \\
\text { in place }\end{array}$ & $\begin{array}{l}\text { the research } \\
\text { process, or loss of } \\
\text { access to data is } \\
\text { unlikely. }\end{array}$ \\
\hline
\end{tabular}

\section{TECHNOLOGY}

Technology covers the requisite equipment, software, hardware, a secure environment, and skills to enable research data management. The key underlying question is: Does the organisation have the necessary technology to satisfy research data management requirements?

T1: Technological Infrastructure: Does the technological infrastructure (e.g. network bandwidth, power, storage) meet research data management needs? Is there sufficient technological capacity to support the volume of research data?

\begin{tabular}{|l|l|l|l|l|l|l|}
$\begin{array}{l}\text { N/A: The statement } \\
\text { is of no relevance to } \\
\text { your situation. }\end{array}$ & $\begin{array}{l}\text { ?: The statement is } \\
\text { of relevance but you } \\
\text { do not know enough } \\
\text { about the situation } \\
\text { to supply a rating. }\end{array}$ & $\begin{array}{l}\text { 1: Technological } \\
\text { infrastructure is } \\
\text { insufficient to meet } \\
\text { data management } \\
\text { needs }\end{array}$ & $\begin{array}{l}\text { 2: Technological } \\
\text { infrastructure is } \\
\text { usually sufficient but } \\
\text { has issues e.g. } \\
\text { reliability }\end{array}$ & $\begin{array}{l}\text { 3: Satisfactory } \\
\text { technological } \\
\text { infrastructure in } \\
\text { place. Capacity is } \\
\text { sufficient. }\end{array}$ & $\begin{array}{l}\begin{array}{l}\text { 4: Technological } \\
\text { infrastructure } \\
\text { functions } \\
\text { seamlessly and } \\
\text { invisibly - it just } \\
\text { works }\end{array} \\
\text { technological } \\
\text { infrastructure that is } \\
\text { also flexible and } \\
\text { scalable to meet } \\
\text { evolving needs }\end{array}$ \\
\hline
\end{tabular}

T2: Appropriate Technologies: Is the necessary equipment available for research data management? Is the necessary software available for research data management? Are open standards understood and employed? Is data lifespan a consideration when choosing technology?

\begin{tabular}{|l|l|l|l|l|l|l|}
$\begin{array}{l}\text { N/A: The statement } \\
\text { is of no relevance to } \\
\text { your situation. }\end{array}$ & $\begin{array}{l}\text { ?: The statement is } \\
\text { of relevance but you } \\
\text { do not know enough } \\
\text { about the situation } \\
\text { to supply a rating. }\end{array}$ & $\begin{array}{l}\text { 1: Necessary } \\
\text { equipment/software } \\
\text { for research data } \\
\text { management is not } \\
\text { available / Low } \\
\text { awareness of } \\
\text { appropriate } \\
\text { technologies for } \\
\text { data management }\end{array}$ & $\begin{array}{l}\text { 2: Some } \\
\text { equipment/software } \\
\text { for research data } \\
\text { management is } \\
\text { available. There } \\
\text { may be insufficient } \\
\text { access to the } \\
\text { equipment/software } \\
\text { or functionality may } \\
\text { be limited / Some } \\
\text { equipment/software } \\
\text { for research data } \\
\text { management is }\end{array}$ & $\begin{array}{l}\text { 3: Necessary } \\
\text { equipment/software } \\
\text { is in place / There is } \\
\text { an organisational } \\
\text { strategy that } \\
\text { promotes } \\
\text { appropriate } \\
\text { technological } \\
\text { approaches }\end{array}$ & $\begin{array}{l}\text { 4: Necessary } \\
\text { equipment/software } \\
\text { is in place and staff } \\
\text { are supported in its } \\
\text { use / Strategy } \\
\text { promoting } \\
\text { appropriate } \\
\text { technologies is } \\
\text { understood and } \\
\text { implemented across } \\
\text { the organisation } \\
\text { equipment/software } \\
\text { continues to be in } \\
\text { place and well } \\
\text { supported / There is } \\
\text { widespread } \\
\text { participation in the } \\
\text { development and } \\
\text { promotion of } \\
\text { appropriate } \\
\text { technologies and } \\
\text { standards within the }\end{array}$ \\
\hline
\end{tabular}




\begin{tabular}{|l|l|l|l|l|}
\hline & & $\begin{array}{l}\text { available. There } \\
\text { may be insufficient } \\
\text { access to the } \\
\text { equipment/software } \\
\text { or functionality may } \\
\text { be limited }\end{array}$ & & institution and \\
beyond & & \\
\hline
\end{tabular}

T3: Ensuring Availability: Are there policies and procedures in place for robust data backup and redundancy? Are there policies and procedures in place to synchronise multiple copies of data? How is the use of removable or local storage regulated?

\begin{tabular}{|l|l|l|l|l|l|}
\hline $\begin{array}{l}\text { N/A: The statement } \\
\text { is of no relevance to } \\
\text { your situation. }\end{array}$ & $\begin{array}{l}\text { ?: The statement is } \\
\text { of relevance but you } \\
\text { do not know enough } \\
\text { about the situation } \\
\text { to supply a rating. }\end{array}$ & $\begin{array}{l}\text { 1: There is low } \\
\text { awareness of the } \\
\text { need for data } \\
\text { backup and } \\
\text { redundancy. There } \\
\text { is little backing up } \\
\text { carried out and } \\
\text { there is a high risk } \\
\text { of data loss. }\end{array}$ & $\begin{array}{l}\text { 2: Backing up is } \\
\text { carried out on an ad } \\
\text { hoc basis by } \\
\text { individuals }\end{array}$ & $\begin{array}{l}\text { 3: A central backup } \\
\text { service is provided. } \\
\text { There are guidelines } \\
\text { in place for backing } \\
\text { up data. }\end{array}$ & $\begin{array}{l}\begin{array}{l}\text { 4: Backup provision } \\
\text { meets appropriate } \\
\text { standards and is } \\
\text { demonstrably } \\
\text { robust. There is an } \\
\text { appreciation of the } \\
\text { importance of } \\
\text { backup among } \\
\text { researchers }\end{array} \\
\text { systematically } \\
\text { coordinated and } \\
\text { managed } \\
\text { throughout. Backup } \\
\text { consists of a rich } \\
\text { array of services } \\
\text { which are frequently } \\
\text { tested and } \\
\text { validated. }\end{array}$
\end{tabular}

T4: Managing Data Integrity: Is data integrity monitored and managed? How is data integrity validated and restored? How is storage media integrity validated?

\begin{tabular}{|c|c|c|c|c|c|c|}
\hline $\begin{array}{l}\text { N/A: The statement } \\
\text { is of no relevance to } \\
\text { your situation. }\end{array}$ & $\begin{array}{l}\text { ?: The statement is } \\
\text { of relevance but you } \\
\text { do not know enough } \\
\text { about the situation } \\
\text { to supply a rating. }\end{array}$ & $\begin{array}{l}\text { 1: Data integrity is } \\
\text { poorly understood } \\
\text { and rarely } \\
\text { considered }\end{array}$ & $\begin{array}{l}\text { 2: Integrity of data } \\
\text { and storage media } \\
\text { may be manually } \\
\text { checked now and } \\
\text { again. Integrity loss } \\
\text { is typically } \\
\text { irrecoverable. }\end{array}$ & $\begin{array}{l}\text { 3: There are policies } \\
\text { and associated } \\
\text { processes in place } \\
\text { to manage data } \\
\text { integrity and } \\
\text { address identified } \\
\text { errors }\end{array}$ & $\begin{array}{l}\text { 4: Policies are } \\
\text { enacted through } \\
\text { automated systems } \\
\text { that monitor and } \\
\text { validate data } \\
\text { integrity at regular } \\
\text { intervals. Integrity } \\
\text { loss is effectively } \\
\text { mitigated e.g. via } \\
\text { backup systems }\end{array}$ & $\begin{array}{l}\text { 5: Systems to } \\
\text { monitor and restore } \\
\text { data integrity are } \\
\text { secure and scalable } \\
\text { to cope with } \\
\text { increasing demand }\end{array}$ \\
\hline
\end{tabular}


T5: Obsolescence: Is potential obsolescence a consideration when selecting technologies for data and data management (e.g., formats, systems, hardware and storage media)? Are open formats and standards prioritised where applicable? How are risks of technological obsolescence identified and resolved?

\begin{tabular}{|c|c|c|c|c|c|c|}
\hline $\begin{array}{l}\text { N/A: The statement } \\
\text { is of no relevance to } \\
\text { your situation. }\end{array}$ & $\begin{array}{l}\text { ?: The statement is } \\
\text { of relevance but you } \\
\text { do not know enough } \\
\text { about the situation } \\
\text { to supply a rating. }\end{array}$ & $\begin{array}{l}\text { 1: Poor } \\
\text { understanding of the } \\
\text { risks of } \\
\text { obsolescence }\end{array}$ & $\begin{array}{l}2: \text { There is some } \\
\text { awareness of how } \\
\text { to manage } \\
\text { obsolescence e.g. } \\
\text { by choosing open } \\
\text { standards }\end{array}$ & $\begin{array}{l}\text { 3: There is an } \\
\text { organisational } \\
\text { strategy to ensure } \\
\text { data remains } \\
\text { accessible and } \\
\text { usable }\end{array}$ & $\begin{array}{l}4: \text { There is a } \\
\text { proactive approach } \\
\text { to managing } \\
\text { obsolescence } \\
\text { throughout the } \\
\text { organisation }\end{array}$ & $\begin{array}{l}\text { 5: Approaches to } \\
\text { obsolescence are } \\
\text { widely acclaimed. } \\
\text { There are significant } \\
\text { contributions to } \\
\text { wider community } \\
\text { understanding. }\end{array}$ \\
\hline
\end{tabular}

T6: Managing Technological Change: How are technology changes planned and implemented? How are processes and changes to those processes documented?

\begin{tabular}{l|l|l|l|l|l|l|}
$\begin{array}{l}\text { N/A: The statement } \\
\text { is of no relevance to } \\
\text { your situation. }\end{array}$ & $\begin{array}{l}\text { ?: The statement is } \\
\text { of relevance but you } \\
\text { do not know enough } \\
\text { about the situation } \\
\text { to supply a rating. }\end{array}$ & $\begin{array}{l}\text { 1: Changes occur in } \\
\text { an ad hoc, } \\
\text { unplanned manner } \\
\text { without reference to } \\
\text { the broader context }\end{array}$ & $\begin{array}{l}\text { 2: Technological } \\
\text { change and the } \\
\text { documentation of } \\
\text { new processes is } \\
\text { managed at a local } \\
\text { level }\end{array}$ & $\begin{array}{l}\text { 3: Technological } \\
\text { advances are } \\
\text { monitored and } \\
\text { changes are } \\
\text { implemented in a } \\
\text { co-ordinated } \\
\text { manner }\end{array}$ & $\begin{array}{l}\begin{array}{l}\text { 4: There is a } \\
\text { strategic and } \\
\text { forward-thinking } \\
\text { approach to } \\
\text { anticipate and } \\
\text { roll-out the } \\
\text { necessary } \\
\text { technological } \\
\text { changes }\end{array} \\
\text { effectively planned, } \\
\text { well communicated } \\
\text { and implemented } \\
\text { with little disruption } \\
\text { to working practice }\end{array}$ &
\end{tabular}

T7: Security Provisions: Are there adequate information security policies and procedures in place? Are technological risks managed? Is access controlled? Are security provisions tested?

\begin{tabular}{|l|l|l|l|l|l|l|}
\hline $\begin{array}{l}\text { N/A: The statement } \\
\text { is of no relevance to } \\
\text { your situation. }\end{array}$ & $\begin{array}{l}\text { ?: The statement is } \\
\text { of relevance but you } \\
\text { do not know enough } \\
\text { about the situation } \\
\text { to supply a rating. }\end{array}$ & $\begin{array}{l}\text { 1: Security is poorly } \\
\text { considered and } \\
\text { there is little } \\
\text { awareness of } \\
\text { exposure to risk }\end{array}$ & $\begin{array}{l}\text { 2: Individual practice } \\
\text { threatens security } \\
\text { e.g. using memory } \\
\text { sticks, laptops, } \\
\text { personal email to } \\
\text { move/store data }\end{array}$ & $\begin{array}{l}\text { 3: There is a good } \\
\text { awareness of } \\
\text { security issues and } \\
\text { relevant policies and } \\
\text { procedures are in } \\
\text { place }\end{array}$ & $\begin{array}{l}\text { 4: Good } \\
\text { implementation of } \\
\text { security policies and } \\
\text { access is } \\
\text { systematically } \\
\text { controlled in all } \\
\text { cases }\end{array}$ & $\begin{array}{l}\text { 5: There are } \\
\text { excellent security } \\
\text { policies, supported } \\
\text { by a robust } \\
\text { technological } \\
\text { infrastructure, both } \\
\text { of which are } \\
\text { regularly reviewed }\end{array}$
\end{tabular}


T8: Security Processes: Are security threats monitored and resolved? Is security infrastructure operated and maintained appropriately?

- N/A: The statement is

of no

relevance to

your

situation.
?: The statement is 1 : The systems in of relevance but you do not know enough about the situation to supply a rating.

\section{place to manage} security are inadequate.

Breaches are frequent and disruptive.

2: Systems are in
place but rely on
ongoing good
practice by
individuals

3: There are a suite of systems in place to manage security. Threats are dealt with but may still impact on working 4: Systems are well adopted and function effectively practice.
5: Security is robustly managed.

Threats are monitored, anticipated and handled efficiently without disruption.

T9: Metadata Tools: Are appropriate technologies available to create metadata in line with standards? Is the process of metadata creation automated where possible? Are tools to make use of metadata available?

\begin{tabular}{|c|c|c|c|c|c|c|}
\hline $\begin{array}{l}N / A \text { : The statement } \\
\text { is of no relevance to } \\
\text { your situation. }\end{array}$ & $\begin{array}{l}\text { ?: The statement is } \\
\text { of relevance but you } \\
\text { do not know enough } \\
\text { about the situation } \\
\text { to supply a rating. }\end{array}$ & $\begin{array}{l}\text { 1: No tools are } \\
\text { available to aid } \\
\text { metadata creation } \\
\text { and use }\end{array}$ & $\begin{array}{l}2: \text { Tools are } \\
\text { available but } \\
\text { metadata creation is } \\
\text { a manual and } \\
\text { time-consuming } \\
\text { process }\end{array}$ & $\begin{array}{l}\text { 3: There is a } \\
\text { significant amount } \\
\text { of automation, } \\
\text { guidance and } \\
\text { support to aid } \\
\text { metadata creation } \\
\text { and management }\end{array}$ & $\begin{array}{l}\text { 4: Metadata tools } \\
\text { are well suited to } \\
\text { researchers' needs, } \\
\text { function well and } \\
\text { are adopted widely }\end{array}$ & $\begin{array}{l}\text { 5: A strategy is } \\
\text { implemented to } \\
\text { maintain good } \\
\text { practice and ensure } \\
\text { appropriate } \\
\text { metadata tools } \\
\text { continue to be in } \\
\text { place }\end{array}$ \\
\hline
\end{tabular}

T10: Institutional Repository: Do you have an Institutional Repository that accepts data, not just publications? To what extent is the repository embedded in research culture/process?

\begin{tabular}{|l|l|l|l|l|l|l|}
$\begin{array}{l}\text { N/A: The statement } \\
\text { is of no relevance to } \\
\text { your situation. }\end{array}$ & $\begin{array}{l}\text { ?: The statement is } \\
\text { of relevance but you } \\
\text { do not know enough } \\
\text { about the situation } \\
\text { to supply a rating. }\end{array}$ & $\begin{array}{l}\text { 1: There is no } \\
\text { Institutional } \\
\text { Repository for data } \\
\text { or appreciation of } \\
\text { the benefits it would } \\
\text { provide }\end{array}$ & $\begin{array}{l}\text { 2: An Institutional } \\
\text { Repository for } \\
\text { research data is } \\
\text { planned or in } \\
\text { development }\end{array}$ & $\begin{array}{l}\text { 3: An Institutional } \\
\text { Repository is in } \\
\text { place, which } \\
\text { accepts data. } \\
\text { Researchers are } \\
\text { aware of the need to } \\
\text { manage data and } \\
\text { how the repository } \\
\text { supports this. }\end{array}$ & $\begin{array}{l}\text { 4: The Institutional } \\
\text { Repository is widely } \\
\text { known and well } \\
\text { used to manage } \\
\text { research data }\end{array}$ & $\begin{array}{l}\text { 5: The Institutional } \\
\text { Repository is well } \\
\text { embedded within } \\
\text { research processes. } \\
\text { The repository is } \\
\text { recognised within } \\
\text { the community and } \\
\text { used as an example } \\
\text { of good practice. }\end{array}$ \\
\hline
\end{tabular}




\section{RESOURCES}

The maintenance and development of a range of resources is required for effective research data management. Elements covered in the Resources section include human resources, financial sustainability, business planning and risk management. The critical underlying questions are: Are sufficient resources in place to ensure institutional research data are effectively managed and shared? Are the institutional resources fit for purpose and sustainable?

R1: Data Management Costs and Sustainability: Are the costs associated with data management understood and accounted for? Are plans in place to ensure resourcing for data management is sustained? Is research data management embedded as a core function and financed appropriately?

\begin{tabular}{l|l|l|l|l|l|l|}
$\begin{array}{l}\text { N/A: The statement } \\
\text { is of no relevance to } \\
\text { your situation. }\end{array}$ & $\begin{array}{l}\text { ?: The statement is } \\
\text { of relevance but you } \\
\text { do not know enough } \\
\text { about the situation } \\
\text { to supply a rating. }\end{array}$ & $\begin{array}{l}\text { 1: Data } \\
\text { management costs } \\
\text { are not considered }\end{array}$ & $\begin{array}{l}\text { 2: Some aspects of } \\
\text { data management } \\
\text { costs are } \\
\text { understood. } \\
\text { Funding is sought to } \\
\text { cover these costs. }\end{array}$ & $\begin{array}{l}\text { 3: Data } \\
\text { management costs } \\
\text { are understood by } \\
\text { individuals and } \\
\text { reflected in research } \\
\text { funding applications }\end{array}$ & $\begin{array}{l}\text { 4: Costs are well } \\
\text { understood and } \\
\text { budgets incorporate } \\
\text { explicit data } \\
\text { management } \\
\text { allocations. }\end{array}$ & $\begin{array}{l}\text { 5: Controls are in } \\
\text { place to ensure the } \\
\text { availability of explicit } \\
\text { data management } \\
\text { funding now and for } \\
\text { the foreseeable } \\
\text { future. }\end{array}$ \\
\hline
\end{tabular}

R2: Business Planning: Is data management a consideration when developing business plans? Is research data management embedded as a core function of the organisation?

\begin{tabular}{l|l|l|l|l|l|l}
$\begin{array}{l}\text { N/A: The } \\
\text { statement is } \\
\text { of no } \\
\text { relevance to } \\
\text { your } \\
\text { situation. }\end{array}$ & $\begin{array}{l}\text { ?: The statement is } \\
\text { of relevance but you } \\
\text { do not know enough } \\
\text { about the situation } \\
\text { to supply a rating. }\end{array}$ & $\begin{array}{l}\text { 1: Data } \\
\text { management is not } \\
\text { a consideration in } \\
\text { wider business } \\
\text { planning }\end{array}$ & $\begin{array}{l}\text { 2: There is some } \\
\text { awareness of the } \\
\text { impact of data } \\
\text { management but } \\
\text { this is not reflected } \\
\text { in strategic plans }\end{array}$ & $\begin{array}{l}\text { 3: Proposals exist to } \\
\text { exploit opportunities } \\
\text { associated with data } \\
\text { management }\end{array}$ & $\begin{array}{l}\text { 4: Business } \\
\text { planning activities } \\
\text { explicitly and } \\
\text { systematically } \\
\text { consider data } \\
\text { management } \\
\text { implications }\end{array}$ & $\begin{array}{l}\text { 5: Data } \\
\text { management is an } \\
\text { intrinsic part of the } \\
\text { organisation's } \\
\text { business and } \\
\text { central to its plans }\end{array}$ \\
\hline
\end{tabular}

R3: Technological Resources Allocation: Are resources sufficient to ensure sustainability and scalability of technology provision? Is technology investment appropriate to data management demands? Are staff equipped to fully exploit technological resources?

\begin{tabular}{|l|l|l|l|l|l|l|}
\hline $\begin{array}{l}\text { N/A: The statement } \\
\text { is of no relevance to } \\
\text { your situation. }\end{array}$ & $\begin{array}{l}\text { ?: The statement is } \\
\text { of relevance but you } \\
\text { do not know enough } \\
\text { about the situation } \\
\text { to supply a rating. }\end{array}$ & $\begin{array}{l}\text { 1: Technological } \\
\text { resources are } \\
\text { insufficient to satisfy } \\
\text { current data } \\
\text { management } \\
\text { challenges }\end{array}$ & $\begin{array}{l}\text { 2: Technological } \\
\text { resources seem to } \\
\text { meet researchers' } \\
\text { data management } \\
\text { needs but the } \\
\text { planning and }\end{array}$ & $\begin{array}{l}\text { 3: Technological } \\
\text { resources support } \\
\text { researchers' current } \\
\text { data management } \\
\text { needs and are } \\
\text { regularly reviewed. } \\
\text { Staff have the skills }\end{array}$ & $\begin{array}{l}\text { 4: Technological } \\
\text { resources are well } \\
\text { allocated to support } \\
\text { data management } \\
\text { needs and } \\
\text { consideration is }\end{array}$ & $\begin{array}{l}\text { 5: Data } \\
\text { management } \\
\text { requirements are } \\
\text { assessed and } \\
\text { explicitly factored } \\
\text { into future } \\
\text { technological }\end{array}$ \\
\hline
\end{tabular}




\begin{tabular}{|l|l|l|l|l|l|}
\hline & & $\begin{array}{l}\text { costing is } \\
\text { uncoordinated }\end{array}$ & $\begin{array}{l}\text { needed to exploit } \\
\text { the technology. }\end{array}$ & $\begin{array}{l}\text { given to how to } \\
\text { sustain this. }\end{array}$ & $\begin{array}{l}\text { resource allocation } \\
\text { to ensure scalability. } \\
\text { Skills are well } \\
\text { distributed across } \\
\text { the team to ensure } \\
\text { technology is fully } \\
\text { exploited }\end{array}$ \\
\hline
\end{tabular}

R4: Risk Management: Does the organisation understand and proactively manage risks associated with data management? Is there capacity to mitigate risks when identified?

\begin{tabular}{|l|l|l|l|l|l|l}
\hline $\begin{array}{l}\text { N/A: The statement } \\
\text { is of no relevance to } \\
\text { your situation. }\end{array}$ & $\begin{array}{l}\text { ?: The statement is } \\
\text { of relevance but you } \\
\text { do not know enough } \\
\text { about the situation } \\
\text { to supply a rating. }\end{array}$ & $\begin{array}{l}\text { 1: Risk exposure is } \\
\text { not formally } \\
\text { evaluated. There is } \\
\text { no capacity to } \\
\text { identify and mitigate } \\
\text { risks. }\end{array}$ & $\begin{array}{l}\text { 2: Risks may be } \\
\text { considered locally or } \\
\text { in a limited capacity. } \\
\text { Potential issues } \\
\text { such as data loss } \\
\text { are poorly } \\
\text { understood. }\end{array}$ & $\begin{array}{l}\text { 3: Good } \\
\text { understanding of } \\
\text { risks associated } \\
\text { with poor data } \\
\text { management. } \\
\text { Organisational } \\
\text { policy requires } \\
\text { maintenance of a } \\
\text { risk register. }\end{array}$ & $\begin{array}{l}\begin{array}{l}\text { assessments are } \\
\text { undertaken and } \\
\text { mitigation strategies } \\
\text { are revised } \\
\text { accordingly. }\end{array} \\
\text { effectively managed } \\
\text { and resources are } \\
\text { available to respond } \\
\text { to risks as identified. }\end{array}$ \\
\hline
\end{tabular}

R5: Transparency of Resource Allocation: Is it clear how resources are allocated to support research data management? Is the income associated with research data management clearly identified and traceable for audit purposes?

\begin{tabular}{|c|c|c|c|c|c|c|}
\hline $\begin{array}{l}\text { N/A: The statement } \\
\text { is of no relevance to } \\
\text { your situation. }\end{array}$ & $\begin{array}{l}\text { ?: The statement is } \\
\text { of relevance but you } \\
\text { do not know enough } \\
\text { about the situation } \\
\text { to supply a rating. }\end{array}$ & $\begin{array}{l}\text { 1: Data } \\
\text { management funds } \\
\text { and resources are } \\
\text { not specifically } \\
\text { covered in income } \\
\text { or expenditure } \\
\text { reporting }\end{array}$ & $\begin{array}{l}\text { 2: Some data } \\
\text { management costs } \\
\text { may be identifiable } \\
\text { in budgets but } \\
\text { practice is ad hoc }\end{array}$ & $\begin{array}{l}\text { 3: Policies } \\
\text { determine how } \\
\text { funding should be } \\
\text { allocated and } \\
\text { available to support } \\
\text { data management } \\
\text { activity and this is } \\
\text { clearly identified }\end{array}$ & $\begin{array}{l}\text { 4: Allocation of data } \\
\text { management } \\
\text { resources is } \\
\text { coordinated and } \\
\text { recorded at an } \\
\text { organisational level }\end{array}$ & $\begin{array}{l}\text { 5: Allocation of data } \\
\text { management } \\
\text { resources is } \\
\text { completely } \\
\text { transparent and } \\
\text { evident in policy and } \\
\text { documentation }\end{array}$ \\
\hline
\end{tabular}

R6: Sustainability of Funding for Data Management and Preservation: Are there sustainable financial resources for research data management? Are efforts made to seek additional funding sources? Are central resources allocated appropriately to support research data management activity?

\begin{tabular}{|l|l|l|l|l|l|l|}
$\begin{array}{l}\text { N/A: The statement } \\
\text { is of no relevance to } \\
\text { your situation. }\end{array}$ & $\begin{array}{l}\text { ?: The statement is } \\
\text { of relevance but you } \\
\text { do not know enough }\end{array}$ & $\begin{array}{l}\text { 1: Resources to } \\
\text { support data } \\
\text { management are } \\
\text { often from short }\end{array}$ & $\begin{array}{l}\text { 2: Central resources } \\
\text { subsidise research } \\
\text { income for research } \\
\text { data management }\end{array}$ & $\begin{array}{l}\text { 3: Staff are centrally } \\
\text { funded to support } \\
\text { data management } \\
\text { activities. Plans are }\end{array}$ & $\begin{array}{l}\text { 4: Plans for } \\
\text { sustainable services } \\
\text { are formally } \\
\text { supported by the }\end{array}$ & $\begin{array}{l}\text { 5: Enough income is } \\
\text { renerated to } \\
\text { resource data }\end{array}$ \\
\hline
\end{tabular}




\begin{tabular}{|l|l|l|l|l|l|}
\hline & $\begin{array}{l}\text { about the situation } \\
\text { to supply a rating. }\end{array}$ & $\begin{array}{l}\text { term competitive } \\
\text { funding and as such } \\
\text { cannot be reliably } \\
\text { sustained. }\end{array}$ & $\begin{array}{l}\text { in place for } \\
\text { sustainable data } \\
\text { management } \\
\text { support services }\end{array}$ & $\begin{array}{l}\text { organisation and in } \\
\text { the process of being } \\
\text { implemented }\end{array}$ & $\begin{array}{l}\text { management } \\
\text { activity sustainably. }\end{array}$ \\
\hline
\end{tabular}

R7: Data Management Skills: Do research staff have the skills they need to undertake research data management? Is there a sufficient support provision and appropriate alignment of skills with roles? Are skills shared within the institution (e.g., to mitigate loss of knowledge due to staff turnover)?

\begin{tabular}{|c|c|c|c|c|c|c|}
\hline $\begin{array}{l}\mathrm{N} / \mathrm{A} \text { : The statement } \\
\text { is of no relevance to } \\
\text { your situation. }\end{array}$ & $\begin{array}{l}\text { ?: The statement is } \\
\text { of relevance but you } \\
\text { do not know enough } \\
\text { about the situation } \\
\text { to supply a rating. }\end{array}$ & $\begin{array}{l}\text { 1: Most staff lack } \\
\text { specific data } \\
\text { management skills } \\
\text { and are poorly } \\
\text { equipped to } \\
\text { undertake such } \\
\text { work }\end{array}$ & $\begin{array}{l}\text { 2: A small number } \\
\text { of individuals have } \\
\text { data management } \\
\text { skills, but their } \\
\text { departure would } \\
\text { leave a skills gap } \\
\text { that would be } \\
\text { difficult to fill. }\end{array}$ & $\begin{array}{l}\text { 3: Data } \\
\text { management skills } \\
\text { are widespread } \\
\text { throughout the } \\
\text { organisation. Good } \\
\text { training and } \\
\text { resource allocation } \\
\text { ensures data } \\
\text { management skills } \\
\text { are maintained and } \\
\text { sufficient support is } \\
\text { provided. }\end{array}$ & $\begin{array}{l}\text { 4: Data } \\
\text { management skills } \\
\text { are well aligned with } \\
\text { roles and formalised } \\
\text { in job descriptions. } \\
\text { A policy of skills } \\
\text { sharing encourages } \\
\text { the transfer of skills } \\
\text { throughout the } \\
\text { staffing resource }\end{array}$ & $\begin{array}{l}\text { 5: Dedicated RDM } \\
\text { support staff are } \\
\text { well known across } \\
\text { the organisation. } \\
\text { DM training is } \\
\text { exemplary and } \\
\text { continuously revised } \\
\text { to reflect changing } \\
\text { demands. Skills are } \\
\text { habitually and } \\
\text { systematically } \\
\text { shared through staff } \\
\text { talks, workshops } \\
\text { and collaborative } \\
\text { activity. }\end{array}$ \\
\hline
\end{tabular}

R8: Number of Staff for Data Management: Are there enough members of staff to undertake and/or support research data management? Are adequate funds available to maintain necessary staff levels? Do you understand the staffing requirements to ensure data management success?

\begin{tabular}{|c|c|c|c|c|c|c|}
\hline $\begin{array}{l}\text { N/A: The statement } \\
\text { is of no relevance to } \\
\text { your situation. }\end{array}$ & $\begin{array}{l}\text { ?: The statement is } \\
\text { of relevance but you } \\
\text { do not know enough } \\
\text { about the situation } \\
\text { to supply a rating. }\end{array}$ & $\begin{array}{l}\text { 1: The number of } \\
\text { staff required has } \\
\text { not been considered } \\
\text { due to a lack of } \\
\text { resources }\end{array}$ & $\begin{array}{l}\text { 2: Some areas are } \\
\text { well supported, but } \\
\text { generally there are } \\
\text { too few people } \\
\text { assigned to data } \\
\text { management roles } \\
\text { to ensure work is } \\
\text { carried out } \\
\text { adequately }\end{array}$ & $\begin{array}{l}\text { 3: Staffing is } \\
\text { currently adequate } \\
\text { to undertake basic } \\
\text { data management } \\
\text { but may need to be } \\
\text { increased as } \\
\text { requirements } \\
\text { change. }\end{array}$ & $\begin{array}{l}\text { 4: Staff numbers are } \\
\text { good and there is } \\
\text { some forward } \\
\text { planning to ensure } \\
\text { these levels are } \\
\text { maintained. }\end{array}$ & $\begin{array}{l}\text { 5: Staff levels are } \\
\text { well managed and } \\
\text { contingency funding } \\
\text { is available to } \\
\text { ensure additional } \\
\text { staff resource can } \\
\text { be procured as } \\
\text { required. }\end{array}$ \\
\hline
\end{tabular}


R9: Staff Development Opportunities: Do researchers have access to data management training and other development opportunities? Is training appropriate for researchers' needs and up to date? Are staff development needs identified, monitored and responded to?

\begin{tabular}{|c|c|c|c|c|c|c|}
\hline $\begin{array}{l}\text { N/A: The statement } \\
\text { is of no relevance to } \\
\text { your situation. }\end{array}$ & $\begin{array}{l}\text { ?: The statement is } \\
\text { of relevance but you } \\
\text { do not know enough } \\
\text { about the situation } \\
\text { to supply a rating. }\end{array}$ & $\begin{array}{l}\text { 1: No resource is } \\
\text { available to support } \\
\text { staff development }\end{array}$ & $\begin{array}{l}\text { 2: Needs are only } \\
\text { identified when } \\
\text { individuals request } \\
\text { training. Relevant } \\
\text { opportunities exist in } \\
\text { some cases but } \\
\text { skills are often } \\
\text { lacking. }\end{array}$ & $\begin{array}{l}\text { 3: A satisfactory } \\
\text { staff development } \\
\text { budget is available } \\
\text { and an appropriate } \\
\text { range of } \\
\text { development } \\
\text { opportunities are } \\
\text { provided. }\end{array}$ & $\begin{array}{l}\text { 4: Specific data } \\
\text { management } \\
\text { training is available } \\
\text { and widely } \\
\text { promoted. Staff } \\
\text { development needs } \\
\text { are regularly } \\
\text { evaluated and } \\
\text { responded to } \\
\text { through improved } \\
\text { development } \\
\text { opportunities. }\end{array}$ & $\begin{array}{l}\text { 5: Staff } \\
\text { development is } \\
\text { evident as a result } \\
\text { of systematic review } \\
\text { and excellent } \\
\text { training provision. } \\
\text { Dedicated funds are } \\
\text { allocated to staff } \\
\text { development, } \\
\text { ensuring skills levels } \\
\text { are sustained. }\end{array}$ \\
\hline
\end{tabular}

